Meta

Journal des traducteurs

Translators' Journal

\title{
Literary Translation and Culture Consciousness: The Experience of Translating D.O. Fagunwa's Igbo Olodumare from Yoruba into English
}

\section{Pamela J. Olubunmi Smith}

Volume 38, numéro 2, juin 1993

URI : https://id.erudit.org/iderudit/004196ar

DOI : https://doi.org/10.7202/004196ar

Aller au sommaire du numéro

Éditeur(s)

Les Presses de l'Université de Montréal

ISSN

0026-0452 (imprimé)

1492-1421 (numérique)

Découvrir la revue

Citer cet article

Olubunmi Smith, P. J. (1993). Literary Translation and Culture Consciousness: The Experience of Translating D.O. Fagunwa's Igbo Olodumare from Yoruba into English. Meta, 38(2), 218-225. https://doi.org/10.7202/004196ar
Résumé de l'article

Le processus de traduction implique l'interprétation précise du sens contextuel du texte-source dans la mesure où les contraintes syntaxiques et associatives de la langue cible le permettent. À cette fin, le traducteur littéraire doit se poser les questions fondamentales suivantes avant de commencer la traduction d'une œuvre : quelle est l'essence stylistique de l'original ? quels en sont l'intention et le but ? Que faire lorsque le texte est culturellement marqué ? C'est en tenant compte de ces interrogations que nous examinerons la traduction du yoruba à l'anglais de Igbo Olodumare de D.O. Fagunwa. 


\title{
LITERARY TRANSLATION AND CULTURE CONSCIOUSNESS: THE EXPERIENCE OF TRANSLATING D.O. FAGUNWA'S IGBO OLODUMARE FROM YORUBA INTO ENGLISH ${ }^{1}$
}

PAMEla J. OlubunMI SMITH

University of Nebraska at Omaha, Omaha, USA

\begin{abstract}
Résumé
Le processus de traduction implique l'interprétation précise du sens contextuel du texte-source dans la mesure où les contraintes syntaxiques et associatives de la langue cible le permettent. À cette fin, le traducteur littéraire doit se poser les questions fondamentales suivantes avant de commencer la traduction d' une ouvre: quelle est l'essence stylistique de l'original? quels en sont l' intention et le but? Que faire lorsque le texte est culturellement marqué? C'est en tenant compte de ces interrogations que nous examinerons la traduction du yoruba à l'anglais de Igbo Olodumare de D.O. Fagunwa.
\end{abstract}

To maintain offhandedly as some translation critics have that translation is impossible is to argue that cultural values are not shareable, and the dialogue of cultures impossible. That the task of making a perfect translation of a literary work is a difficult one is perhaps a more meaningful issue to engage what with the contradictory demands the translator faces when he or she is told that a "good" translation is both literal and not literal, both interpretive and not interpretive.

Notwithstanding the proliferation of literature of what translation is or should be, every translator accepts as basic the definition of translation as "the replacing of textual material in one language (the source language) by equivalent textual material in another language (the target language). In other words, the translation process involves the rendering of the precise contextual meaning of the original text in as far as the syntactic and associative constraints of the target language allow.

To this end, the translator should examine three crucial questions at the beginning of each literary translation: What is the artistic fabric of the original text? What is the intent of the text? What is the purpose of the translation? What is the role of the translator when the text belongs to a cultural system?

Cultural shifts, ever so slight or radical, lead to inapt lexical choices which distort the original meaning of the text. Since literary texts involve matching at the syntactic and phonological levels, the application of semantic code change based on socio-cultural context underscores the need for a keen awareness of "the socio-cultural significance of the place, time, society, register and purpose of the original work." For a thorough stylistic analysis of the text, an insight into the context, and an awareness of the author's syntactic and stylistic intentions, as well as the socio-cultural associations conjured up by lexeme are paramount.

Because language operates within and as part of culture, the context of the language of the text inevitably valorizes the meaning of the (culture bound) text. The notion of the translator as an impersonator who must know something of the author's culture raises a 
crucial question for the translator of African literary texts: What is essential in translating the view from within into a language (usually European) that is essentially from without? Steiner's (1975) argument for "a radical form of hermeneutics" is reiterated here for what amounts simply to the challenge of total interpretation which necessarily involves the culture and the context and space of the text. Do we then mean by this that because of their affinity with African cultures, African translators are the only ones with enough competence to elucidate African texts?

The criteria for judging the accuracy of translation delineate as essentials competency in textual analysis; technical linguistic necessity - that is, competency in and facility with both the source language (SL) and the target language (TL); an essential identification with the author; a thorough grasp of the inner workings of the source culture; and knowledge of the target culture. Impersonation may be easier for the African translator, however, affinity with the source language and culture alone will not necessarily make him or her a better translator. His or her bilingualism must necessarily be shored up with an ability to transfer cultural thoughts, ideas, and sensibilities from indigenous African languages into European languages.

In his essay "Problem of Language in African Writing: The Example of the Novel," Obiechina (1973:15) delineates this "concept-in-context" sensitivity to transferring meaning from indigenous African languages into European languages, calling it "fidelity to social and cultural fact." The African creative writer writing in a European language (mainly English and French) and the translator of African literature written in European and indigenous African languages are confronted with a common linguistic dilemma, that is: How to reproduce equivalent cultural experiences in European languages and still retain the rhythm and structure of the oral tradition inherent in the African original? Obiechina (p. 12) spells out the dilemma thus:

The West African [writer] has to transfer his structure of thought, feeling and expression from a West African language into English, has to recast his material in a fundamental way if his West African experience is to remain West African, while at the same time making sure that the English in which it is expressed remains intelligible to users of the English language all over the world.

If this "fidelity to social and cultural fact" poses a problem for African creative writers writing in European languages, one need only imagine the enormity of the dilemma the translator faces especially when the translator is "a stranger" to the socio-cultural system of the text. Such was the case (though not admitted) in the English translations of Guinean writer Camara Laye's L' Enfant Noir by James Kirkup, and Ernest Jones. The misreadings of the Malinke culture and the resulting mistranslation of the two English versions ${ }^{2}$ of L'Enfant Noir annotated in an essay by Eloise Briere (1988:33-39) evidence the inadequacy of the translators' sheer technical linguistic fluency in transferring into English those Guinean realities which are expressed in French. As Eloise Briere noted, the numerous discrepancies between the English translations and the French original - the Kirkupization of the original text in other words - cannot be blamed on the shortcomings inherent in translation since the translational errors were due to several causes, among them "errors pure and simple, misreadings of Malinke culture...lack of true equivalents in English, and infelicitous lexical choices..." Consequently, we would naturally conclude that a purely eurocentric approach to translating African literary texts, and a lack of affinity between translator and author (as were the case in the L'Enfant Noir example), would and do inevitably result in misreadings and "infelicitous lexical choices that cheat the text of its original meaning." 
Inevitably, the first and most exasperating difficulty the translator is confronted with is the fundamental differences between the source language and the target language. In translating D. O. Fagunwa ${ }^{3}$, the fundamental differences between Yoruba and English began with the highly tonal nature of Yoruba, and manifested themselves in the profuse use of such linguistic forms as proverbs, riddles, metaphors, onomatopoiea, and exaggeration in the Yoruba language, and in such cultural semantics and symbols as the Yoruba forest, incantation, spirits, and so on - characteristics which are not shared by both languages, cultures, or worldviews.

\section{THE EFFECT OF TRANSLATION}

At the beginning of the translation, the problems of the greater gap between the translation of the hermeneutic view and translation of the (Yoruba) linguistic code were evident. Hence the many questions ranging from the general (for example, how does one handle the syntactical possibilities of and availability of alternatives in Yoruba when they are lacking in English?), to the more specific (for example, how does one adequately translate those idiomatic expressions, those "ijinle Yoruba" as Fagunwa called them, and the profuse use of proverbs, similies and metaphors which describe the cultural atmosphere in which characters evolved and action unfolds?) Recognizing from the outset that the restraints of lexical and syntactical peculiarities, especially Fagunwa's stylistic subtleties and structural devices, will be paramount, I risked directness of language and stylized refinement almost to the point of oversimplification of language, and opted to channel energies into achieving the goal of transcribing what Soyinka and other Yorubaspeaking scholars and critics ${ }^{4}$ have identified as the essence of Fagunwa's art, that is the "vivid sense of event and the fusion of sound and action."

Throughout the translation, euphony was a challenge, and admittedly became an obsession. The task clearly was how to transcribe the figurative implications and the tone of Fagunwa's narratives, and achieve the interplay of sense and sound so that the imagery would be resonant with the vitality of the Yoruba original. The obligation then was to try to retain the sound of the original and to reproduce the effects that depend on the emphasis of sound, the rhythmic cadences such as alliteration and assonance for the translation to constitute a novel in its own right.

As was the case in Wole Soyinka's free translation of Fagunwa's first novel, Ogboju Ode Ninu Igbo Irunmale, 1938 (The Forest of a Thousand Daemons 1968), the pattern of choices in translating Fagunwa's second novel, Igbo Olodumare (The Forest of the Almighty) began early and ranged from the novel's very title to issues of the characters' names, hyperbolic language, idiomatic equivalences and the rendering of Fagunwa's deliberate rhetorical and rhythmic effects. Since Fagunwa conceived of and indeed wrote Igbo Olodumare (1949) as a sequel to Ogboju Ode Ninu Igbo Irunmale (hereafter Ogboju Ode), Soyinka's choice of "forest" for igbo in lieu of "jungle" necessarily impacted and indeed handicapped any alternative choices for igbo. In spite of its less than sacred connotation, "jungle" in my judgment would have conveyed the meaning and intended essence of Fagunwa's, hence Yoruba culture's, sense of igbo as dense, awe-inspiring, and mysterious, a metaphysical force with vast potential occult energy. Obiechina's (1975: 47) comments on a virgin tropical forest would describe the awe of Fagunwa's forest with all its inscrutability and as a source of enlightenment:

The grandeur of the virgin forest is a terrible kind of beauty, but beauty all the same; for in the traditional imagination, power is an aspect of beauty, and so is mystery. Power is the expression of vitality mixed with mystery. The forest manifests power, natural and supernatural power, with its unlimited scope for mystery. The feeling it inspires is awe tempered with fear. (my emphasis) 
On the one hand, the tameness, the sense of orderliness that for instance, an English "Sherwood Forest" connotes to a Briton or the California "Redwood Forest" to an American somehow seems inadequate in conveying the intensity of Fagunwa's animated world especially to Yoruba-speaking readers who are all too familiar with the awesome tropical rain forest. On the other hand, the connotative values of "jungle" as disorderly, unmysterious to a Western reader is equally fraught with inappropriate images of the symbolically ordered universe, the forest with all its inscrutability and enlightenment which Fagunwa intended. Unfortunately, "bush," a possible third alternative which seemed to have adequately conveyed the strange dynamic "other worldness" of Amos Tutuola's The Palm-wine Drinkard (1952) is, like "forest" and "jungle," inadequate to carry the weight of Fagunwa's "igbo," and the forces of the dark forest where the mysteries of the universe and the drama of man's destiny are ordered and played out.

\section{TRANSLATIONAL TECHNIQUE}

Consequently, I chose a tri-combinational method in order to achieve the purpose and capture the rhythm, and the "vivid sense of event and the fusion of sound and action," in lieu of a "free" translation method. In keeping faith with Fagunwa's style and sensibility, and admittedly, in order to facilitate the translation, I chose to combine the literal, the idiomatic, and the paraphrastic. As appropriate, I used, though sparingly, modified literal word for word rendition of the original to transfer grammatical units, and resorted mostly to idiomatic translation in which I used some English "idiomatic" devices and equivalences to reproduce the intended meaning of the Yoruba original. However, in cases where lexical equivalents for concepts which are unknown in the receptor culture posed a problem, resorting to the paraphrastic method in which the sense of the Yoruba is freely interpreted and transferred into English was more inventive. For example, the moralizing passages in Igbo Olodumare which are numerous, lent themselves to easy idiomatic transference since the majority of Fagunwa's sermonettes have Christian overtones which have direct biblical equivalents. The following examples illustrate this:

$\mathrm{Ki}$ bee ni yin je beeni, Ki beeko yin si je beeko. (Igbo Olodumare, p. 163)

Let your yea be yea and your nay (be) nay.

Ti o ni oju to ko le fi riran, ti o ni imu ti ko le fi gborun, ti o ni eti ti ko le gboran (Igbo Olodumare, p. 118)

(They) that have eyes but see not; that have noses but smell not; that have ears but hear not.

However, in cases in which idiomatic equivalents seem to exist out of context but are meaningless contextually, it was judicious to use either the paraphrastic method or resort to descriptive phrases to clarify the reference. For example, the problem of the Yoruba aphorism Ibi Kerere ni nKan ti ilo... - which ordinarily, out of context, could be translated as one or the other of the English proverbs: "a stitch in time saves nine" or "from tiny acorns oak trees grow." However, when either of these equivalents are contextually applied to the passage below, the sense and meaning of this proverbial statement made by a mouse to Olowo-aiye, the invincible hunter whose imprudence got him stranded on top of a tree, are distorted:

Ibi kekere ni nkan ti ilo, eniti a ran ni ise ti o nsire loju ona, alafojudi eda ni; eniti a fun ni nkan kekere ti ko dupe lowo eni, alaimore ni; eniti a fi ese ko ti ko se ni ni pele alaimokan ni... (lgbo Olodumare, p. 58)

From tiny acorns oak trees grow or a stitch in time saves nine; The man who is sent on an errand but dawdles is an impertinent fool; he who neglects to show gratitude for a gift, no matter how small, is an ingrate; the person whose foot causes us to stumble but shows no 
sympathy is an ignorant fool. Now I must be on my way. I am rather in a hurry. (The Forest of the Almighty, p. 58)

While the language of the two English proverbs seems to fit the elegant language of the moralizing, "from tiny acorns oak trees grow" or "a stitch in time saves nine" is grossly inappropriate in conveying the meaning and intent of the message which is simply an admonition and should therefore read thus:

It is from small slips that a man forms bad habits. I've been sent on an errand by the Council of animals. If I take time off and slip on that responsibility, there's no telling where a little slip here and a little slip there might lead...

The transcription of idiomatic expressions, what Fagunwa called "ijinle Yoruba," that is "deep Yoruba idioms," posed enormous problems no doubt, admittedly more so because of my acute sensitivity to the goal of preserving the auditory beauty of Fagunwa's style. Ulli Beier (1965), the German-born critic of African literature said it well when he commented that "Fagunwa's language is enlivened by a frequent and often startling use of personification." In Fagunwa's hands, even Yoruba idiomatic expressions are imbued with peculiar stylistic subtleties, and the Yoruba penchant for circumlocution no doubt was stretched to its limit.

Consider the following examples. Instead of "expressing" exasperation directly by the statement Oran na su mi (I am fed up with the matter/the matter frustrates me/I am befuddled/I am exasperated), Fagunwa makes his narrator convey total exasperation in extremely visual but circumlocutious language thus:

...mo sun mo Kan ogiri na wayi, mo gbe ebo koja mosalasi, mo fi elede je sarin, mo sun ogede dudu fun Oyinbo je, mo ni ki Hausa Ko goro sile, mo wipe Yoruba ko gbodo je eko... oro yi bi mi ninu tobe ti nko fi so ro si Baba-onirungbon-yeuke titi a fi de ile. (my emphasis, Igbo Olodumare, p. 92)

I had now backed myself into a corner, I knew there was no way out of the mess. I had carried the sacrifice meant for the mosque beyond it, and had broken the Moslem holy fast by eating pork for my early predawn meal; I had offered a white man some roasted green plantain and had asked the Hausa and the Yoruba to do the impossible - the one to give up his Kola nut, the other, his eko. This matter upset me no end that I said not another word to Baba-onirungbon-yeuke until we arrived at his house. (my emphasis, The Forest of the Almighty, p. 96)

Not only is it inconceivable in Yoruba Muslim tradition to carry sacrifices meant for a mosque past it, but it is the height of sacrilege for a Moslem to eat pork in the first place, not to speak of breaking his holy fast with it; a white man is certainly not used to eating roasted ripe plantain let alone a roasted unripe one; and to ask the Hausa and the Yoruba who are passionate lovers of Kola-nut and eko respectively, to sacrifice them is plain ludicrous. The narrator could have effectively expressed the hopelessness of his plea by simply saying, "I had exceeded a reasonable limit" and left it at that. And what temptation such choice is for the translator who wearies of Fagunwa's penchant for repetition and exaggeration!

Instead of "fleeing fast" from intense danger, Fagunwa has his narrator "hold a rapid dialogue with his legs" (ba ese soro) to create a visual effect and delineate the velocity with which the escape was made. For the English idiomatic expression "seeing is believing," Fagunwa uses the more visual concrete Yoruba oju ni oro wa, literally, "it is in the eyes that the matter is," meaning, telling is nothing compared to touching/feeling the matter with the eye. To convey "swiftness," Fagunwa chooses Eiye ko so ka (hardly 
had the bird pecked the grain when...), a culture-specific expression whose impact is lost in translation to a less agrarian reader used to such English equivalents as "promptly," "instantly," "immediately," "at once" which convey the Yoruba Kiakia. To convey the intensity and brilliancy of an unusually sunny, muggy, tropical afternoon, Fagunwa uses the idiomatic expression osan pon gidigidi, literally, "the afternoon was ripe indeed," meaning the sun put the afternoon at its zenith. Where the less visual and impactful o yo si mi, "he appeared/showed up" would perhaps have sufficed to convey the author's arrival for a prearranged story telling session, Fagunwa has him "flash into the [narrator's] line of vision like a spirit" (O yo si mi gbula bi ebora). Even Olowo-aiye's justification of his human essence before the formidable spirit, Esu-Kekere-ode, with whom he must wrestle is a dramatic vaunt addressed to all the forces of the forest. "Any spirit who defies my person would risk being hurled from sphere to sphere" (ebora ti o ba fi oju di mi, yio ma ti orun de orun...).

The examples above are given because they reflect in part a bold inventiveness which is typical of Yoruba prose style. They also substantiate Soyinka's apt remark about the essence of Fagunwa, his verbal dexterity, and his vivid sense of event.

While the choice to leave the proper names and some culture-specific items of a culinary nature is not terribly satisfactory, selecting equivalents for mere auxiliaries diminishes their symbolic validity. Such is the case with the translation of the characters' names and their epithets, especially when Fagunwa used the latter slightly outside convention for comic relief. For example, knowledge of the epic-like nature of Yoruba oriki (praise names) helps to prevent a mistranslation of Fagunwa's description of the wouldbe narrator, Akara-ogun, as:

Okunrin meta, Akara-ogun, $a$-ba-olonje-ku, superman (i.e. three men in one), Akara-ogun, the one who accompanies the cook to the grave.

Out of context, abolonjeku literally means glutton. However, within the context of the complete oriki, the profile of the word abolonjeku is not in keeping with the intent of the message. Consider this literal contextual translation of the oriki:

Okunrin meta, Akara-ogun, abolonjeku, eniti o ba Agbako ja ninu Igbo Irunmale, eniti o rin irinajo ti Oke Langbodo bo, eniti o wa si ile mi ni ijosi, ti irohin na gba gbogbo orile ede yi kankan. (Igbo Olodumare, p. 4)

Ilustrious superman, Akara-ogun, the world-renowned glutton who practically would die with a person provided with plenty of food, the man who wrestled Agbako in the Forest of four hundred spirits, who journeyed successfully to Mount Langbodo; the very man whose visit to my house the other day caused quite a stir throughout this land... (The Forest of the Almighty, p. 4)

In this case, the emotive meaning of "abolonjeku" is purposely mixed. Here, Fagunwa intentionally mixes irony, humor, and a hint of sarcasm with the more serious. Abolonjeku in the context of the other epithets is intended to convey the sense of limitless energy. It is a metaphoric stretching and balancing of Akara-ogun's gastronomic level with his renowned prowess. In other words, in all things, the man has a positively limitless level of energy. Thus, in keeping faith with Fagunwa's emotive meaning, the following translation of the oriki would be more appropriate:

Valorous Akara-ogun, the one whose limitless energy stretches beyond gastronomic proportions, the world-renowned creature who wrestled Agbako in the Forest of four hundred spirits; indeed, the one who journeyed with great success to Mount Langbodo; the very man whose visit to my house the other day still resounds throughout this land... 
Like the example of this epithet, the name Olowo-aiye might be matched with the classical equivalent "World Croesus" at the risk of imbuing Olowo-aiye, the invincible hunter, with characteristics Fagunwa never intended. While Olowo-aiye is rich in renown, medicines and charms, he is by no means monetarily rich, in which case the literal translation of the two words Olowo (owner of money), aiye (world) meaning "World Millionaire" would be grossly inappropriate and inaccurate. While Esu (Devil) could justifiably be translated as "Satan" or "Lucifer," and is indeed generally equated with the Christian concepts of Satan or the Devil on account of the bunyanesque influence on Fagunwa, it is not to be mistaken for the Yoruba deity, Esu, whose positive attributes include the power to bestow children. And for consistency, even the more obvious bunyanesque equivalents such as Iku (Death) and Arun (Disease), though identified by their characteristics in the text, are preserved in the original tongue.

Unlike earlier francophone literature, particularly in the example of the translations of Camara Laye's L'Enfant Noir where differences in the intended audiences were factors, the question of audience, though important, was the least problematic of concerns in translating Fagunwa. Fagunwa's own preface to Igbo Olodumare delineated an avowed aim "to entertain, edify, and transmit wisdom" to a local and a universal audience. The overriding concern therefore was to achieve a balance of style in the target language in order to achieve the universal appeal which Fagunwa intended.

The textual and contextual translational difficulties were relatively surmountable in spite of the general conviction of Yoruba scholars and critics that Fagunwa is very difficult to translate into English. In spite of my obsession with euphony, inevitably, there was some loss in melody and evocative power. Retrospectively, what proved troubling was the seeming cynicism of skeptics whose concern for textual preservation, though genuine, betrayed their bias for translation. This uncertainty that any translation of Fagunwa's novels could possibly come close to telling it in English "the way Fagunwa told it in Yoruba" without dulling their verbal brilliance raised the issue of textual authority, fidelity and creative freedom, an issue which constitutes the second part to this essay. However, the caveat that better a literal translation of Fagunwa than no translation at all buoyed my conviction that the essence of Igbo Olodumare can survive the inhibitions of English idioms.

\section{Notes}

1. This translation was undertaken in 1976 and completed in 1984 . Its publication is pending copyright permission from the late author's son and Nelson-Pitman Publishers of Nigeria.

2. Two translations of L'Enfant Noir were made. The first, entitled The Dark Child, was translated for a North American audience by James Kirkup and Ernest Jones, and published by Noonday Press in 1954. The second, a British version and more accurately titled The African Child, was translated by James Kirkup in 1955, and was published by Fontana / Collins Press.

3. An eminent Yoruba writer, Fagunwa's creative genius is chronicled in five seminal novels, one co-authored travel book, two school readers, and an unfinished novel. He is known as the father of the Yoruba novel, and promoter of Yoruba culture.

4. During my visit to Nigeria in December 1985, I spoke with Yoruba scholars and critics Professors Ayo Bamgbose, Niyi Osundare, Abiola Irele (all of University of Ibadan).

5. To date, Soyinka's 1968 translation remains the only published translation available of Fagunwa's seminal novels. Two unpublished English translations of his second novel, Igbo Olodumare have been made by Ajadi (1984) and Smith (1984). All of his five novels have been translated into French by J.O. Abioye. These also await publication. 


\section{REFERENCES}

BASSNETT-MCGUIRE, Susan (1980): Translation Studies, London, Methuen

BRIERE, Eloise (1988): "In Search of Cultural Equivalencies: Translations of Camara Laye's L'Enfant Noir," Translation Review, 27, pp. 34-39.

CATFORD, I. C. (1965): A Linguistic Theory of Translation, London, OUP.

IRELE, Abiola (1981): "Tradition and the Yoruba Writer: D.O. Fagunwa, Amos Tutuola and Wole Soyinka," in The African Experience in Literature and Ideology, Heinemann.

LEVY, Jiri (1963): "The Art of Translation," Prague, cited in The Nature of Translation, J.S. Holmes ed., The Hague, Mouton, 1970.

OBIECHINA, Emmanuel (1973): "Problem of Language in African Writing: The Example of the Novel," The Conch, Vols. \#1 \& \#2, pp. 11-28. Culture, Tradition, and Society in the West African Novel, Cambridge, CUP, 1975.

SOYINKA, Wole trans. (1968): The Forest of A Thousand Daemons. Nelson.

STEINER, George (1975): After Babel: Aspects of Language and Translation, London, OUP. 